\title{
Treatment of dry eye by autologous serum application in Sjögren's syndrome
}

Kazuo Tsubota, Eiki Goto, Hiromi Fujita, Masafumi Ono, Hiroko Inoue, Ichiro Saito, Shigeto Shimmura

\begin{abstract}
Aim-To evaluate the efficacy of autologous serum application for the treatment of dry eye in Sjögren's syndrome.

Methods-The stability of essential components (EGF, vitamin $A$, and TGF- $\beta$ ) in preserved serum were examined following preservation at $4^{\circ} \mathrm{C}$ and $-20^{\circ} \mathrm{C}$. In a primary clinical trial, 12 patients with Sjögren's syndrome were treated with autologous serum (diluted to $20 \%$ with sterile saline) for 4 weeks, and vital staining of the ocular surface was compared before and after treatment. The effects of serum on mucin (MUC-1) expression were observed in cultured conjunctival epithelial cells in vitro.
\end{abstract}

Results-EGF, vitamin A, and TGF- $\beta$ were well preserved for up to 1 month in the refrigerator at $4^{\circ} \mathrm{C}$ and up to 3 months in the freezer at $-20^{\circ} \mathrm{C}$. Rose bengal and fluorescein scores improved significantly from the initial scores of 5.3 and 5.6 to 1.7 and 2.5 after 4 weeks, respectively. The additive effect of human serum for cultured conjunctival epithelial cells showed significant MUC-1 upregulation on the cell surface.

Conclusion-Autologous serum application is a safe and efficient way to provide essential components to the ocular surface in the treatment of dry eye associated with Sjögren's syndrome.

(Br F Ophthalmol 1999;83:390-395)

Dry eye associated with Sjögren's syndrome (SS dry eye) is often more severe than non-Sjögren dry eye (non-SS dry eye). ${ }^{1-3}$ Rose bengal staining, fluorescein staining, impression cytology, and brush cytology show greater changes in SS dry eye owing to a lack of both basic tearing and reflex tearing resulting from lacrimal gland destruction by infiltrating lymphocytes, which is the hallmark of deteriorating clinical conditions. ${ }^{1-5}$ Accumulated knowledge in the past decade has demonstrated the importance of tear components such as epidermal growth factor (EGF) and vitamin $\mathrm{A}$ in the regulation of proliferation, differentiation, and maturation of the ocular surface epithelium. ${ }^{6-11}$ A deficiency of these components can disrupt the normal proliferation and maturation process of the epithelium. In non-SS dry eye, tear components are supplied to the ocular surface through occasional reflex tears. Thus, the problems associated with the complete depletion of essential tear components are not as expected in non-SS dry eye, where only a slight alteration of the ocular surface is observed. ${ }^{12}$ However in SS dry eye, tear components are lacking to the extent that the integrity of the ocular surface is compromised, resulting in the disruption of the ocular surface epithelium. $^{245}$

In 1984 Fox et al reported the beneficial effects of autologous serum application to dry eye in Sjögren's syndrome. ${ }^{13}$ The rationale for their observation was based upon the fact that vitamins or growth factors present in tears are also present in serum. The application of autologous serum offers an advantage over the simple use of artificial tears which lack such essential components. ${ }^{14}$ Our recent experience with frequent use of autologous serum in the reconstruction of the ocular surface in severe dry eye such as ocular pemphigoid or StevensJohnson syndrome supports the concept that the lack of biologically active tear components can be replaced by autologous serum application..$^{15} 16$

The present study was designed to determine the efficacy and safety of autologous serum application in the treatment of epithelial disorders associated with SS dry eye. The stability of the serum was assessed by measuring the concentration of EGF, TGF- $\beta$, and vitamin $A$ in fresh serum samples, and after preservation in the freezer $\left(-20^{\circ} \mathrm{C}\right)$ and refrigerator $\left(4^{\circ} \mathrm{C}\right)$ for up to 3 months. In a clinical trial, diluted serum solutions $(20 \%$ serum, $80 \%$ saline $)$ were prepared from venepunctured whole blood of SS patients, and various subjective and objective clinical variables were analysed. Used bottles were collected at the end of the study to test for possible contamination. An in vitro study was also performed in order to determine the effects of serum on mucin (MUC-1) expression in cultured conjunctival cells as a possible therapeutic mechanism of serum. 


\section{Materials and methods}

PREPARATION OF AUTOLOGOUS SERUM AND ITS APPLICATION TO DRY EYE

Tears contain essential components for the ocular surface such as EGF, vitamin A, TGF- $\beta$, fibronectin, and various other cytokines. Since these components are also found in serum, we formulated artificial tears by diluting serum obtained from SS patients after informed consent was obtained. A total of 40 $\mathrm{ml}$ of blood was procured by venepuncture and centrifuged for 5 minutes at $1500 \mathrm{rpm}$. The serum was carefully separated in a sterile manner and diluted by saline to $20 \%$. The final preparation was aliquoted into $5 \mathrm{ml}$ bottles with ultraviolet light protection since vitamin A is easily degraded by light. Patients were instructed to keep the bottle in a dark and cool place, such as a refrigerator, while in use with the rest being stored in a freezer until required. Serum drops were applied 6-10 times a day in addition to the old regimen of frequent preservative-free artificial tears, highly viscous hyaluronic acid (Hyalein, Santen Pharmaceutical Co, Osaka, Japan) four times daily, and the use of special dry eye glasses for added humidity. These glasses maintained the moisture level around the eye at $40-80 \%$, depending on the ambient humidity, while the $0.3 \%$ hyaluronic acid offered additional lubrication. ${ }^{17}$ Patients were instructed to use autologous serum (diluted to $20 \%$ with saline), 6-10 times a day for 4 weeks and vital staining of the ocular surface was compared before and after treatment.

MEASUREMENT OF ESSENTIAL TEAR COMPONENTS The concentration of EGF, vitamin $A$, and TGF- $\beta^{18}$ in preserved serum $(n=10)$ were measured under the following conditions; (1) immediately after preparation, (2) after 1 week and 1 month of preservation in the refrigerator $\left(4^{\circ} \mathrm{C}\right),(3)$ after 1 month and 3 months of preservation in the freezer $\left(-20^{\circ} \mathrm{C}\right)$. The biological activity of the cytokines or vitamin A were not measured in this study.

EGF was measured by the homologous radioimmunoassay (RIA) method as previously described by Hirata and Orth. ${ }^{19}$ Vitamin A was
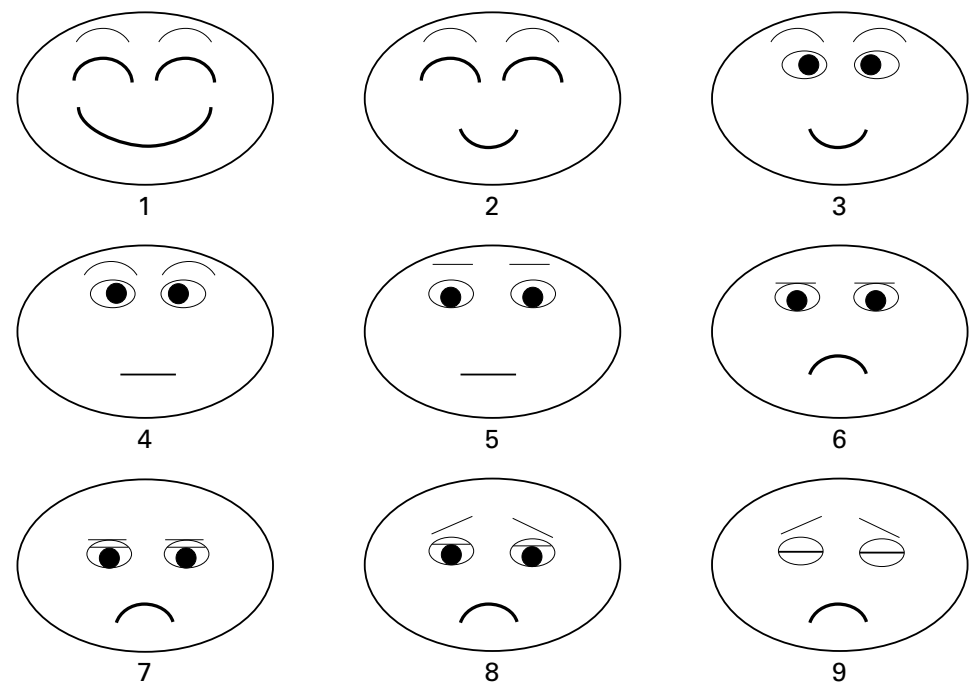

Figure 1 Face score, nine different expressions describing the condition of patients' eyes. measured by high pressure liquid chromatography (HPLC) as reported by Katsui. ${ }^{20}$ TGF- $\beta$ was measured by the human TGF- $\beta 1$ sandwich enzyme immunoassay technique (Quantikine, R \& D systems, Minneapolis, MN, USA) according to the protocol by the manufacturer.

TEAR EVALUATION

To evaluate tear dynamics, the Schirmer test with or without topical anaesthesia was performed, while maximum tear production was evaluated by the Schirmer test with nasal stimulation. This test measures the maximal tear secretion from the ipsilateral eye. Briefly, the patients were checked by the simple Schirmer test for 5 minutes without topical anaesthesia. ${ }^{5}$ Then a cotton swab was inserted into the patient's nasal cavity towards the entrance of the ethmoid sinus. The Schirmer strip of paper was placed on the conjunctival sac as with the ordinary Schirmer test for 5 minutes while the cotton swab was kept in place. The final measurement of tear production was performed on an alternative day and performed in the same manner as the ordinary Schirmer test by measuring the wet length of the test strip. Values of less than $10 \mathrm{~mm}$ with nasal stimulation is an indicator of severe loss of tear production. ${ }^{21}$

OCULAR SURFACE EVALUATION

The ocular surface was examined by the double staining method. Two $\mu$ of preservative-free solution consisting of $1 \%$ rose bengal and $1 \%$ fluorescein dye were applied to the conjunctival sac. $^{22}$ The intensity of rose bengal staining was recorded in the temporal and nasal conjunctiva and the cornea, each graded on a scale of 0 to 3 points. Thus, the maximum score obtained from the staining of one eye is 9 . Fluorescein staining was also rated from 0 to 9 , but only in the cornea. Statistical analysis was performed using the Wilcoxon signed rank test.

In three patients, impression cytology was performed before serum application and 1 month after application by a method developed by Tseng in order to evaluate squamous metaplasia. $^{23}$

RECRUITMENT OF SS DRY EYE PATIENTS

The diagnosis of dry eye was made based on the following three criteria as previously reported: (1) symptoms of dry eye, (2) abnormalities of tear dynamics determined by Schirmer test $(5 \mathrm{~mm})$, clearance test $(8 \times)$, cotton thread test $(10 \mathrm{~mm}),{ }^{24}$ and tear break up time (BUT, 5 seconds), ${ }^{25}$ (3) abnormalities of ocular surface determined by rose bengal $(>3+)$ or fluorescein vital staining $(>3+) .{ }^{2}{ }^{25}$ When patients met all three criteria, they were diagnosed as "definite dry eye". The vital staining was done using a fixed concentration and volume of dye in order to obtain stable results.

Overall subjective comfort was checked by a questionnaire using a face score which consists of nine faces, each showing a different expression. Patients were asked to select which face best describes the current condition of their eyes-for example, a very sad face describes a bad condition of the ocular surface (No 9 on 
Table 1 Preservation of serum in refrigerator

\begin{tabular}{llll}
\hline Preservation & $E G F(n g / m l)$ & $\begin{array}{l}\text { Vitamin } A \\
(\mu g / d l)\end{array}$ & $\begin{array}{l}T G F-\beta 1 \\
(n g / m l)\end{array}$ \\
\hline Initial day & $0.51(0.08)$ & $45.5(19.1)$ & $33.2(6.8)$ \\
1 week & $0.50(0.10)$ & $45.5(19.0)$ & $32.9(81)$ \\
1 month & $0.51(0.08)$ & $49.7(20.5)$ & $32.1(4.7)$ \\
\hline
\end{tabular}

Table 2 Preservation of serum in freezer

\begin{tabular}{llll}
\hline Preservation & $E G F(n g / m l)$ & $\begin{array}{l}\text { Vitamin } A \\
(\mu g / d l)\end{array}$ & $\begin{array}{l}T G F-\beta 1 \\
(\mathrm{ng} / \mathrm{ml})\end{array}$ \\
\hline Initial day & $0.61(0.06)$ & $52.6(12.2)$ & $53.9(4.7)$ \\
1 month & $0.53(0.03)$ & $49.1(11.3)$ & $53.7(4.8)$ \\
3 months & $0.53(0.06)$ & $48.3(10.3)$ & $51.4(5.9)$ \\
\hline
\end{tabular}

face score) and a happy face describes no irritation to the ocular surface (No 1 on face score) (Fig 1). Specific subjective complaints were divided into nine categories with maximum scores of 9 and a minimum of 1 , which were graded by patients before, 2 , and 4 weeks after the treatment. ${ }^{26}$

Among the dry eye patients, the diagnosis of SS type dry eye was made according to a modified version of Fox and Saito's criteria ${ }^{27}$ and decreased reflex tearing. ${ }^{21}$ Patients with severe ocular complaints were recruited for this study since patients with only slight subjective complaints lacked the motivation to enrol in the study that required drawing blood by venepuncture. A total of 12 SS dry eye patients were recruited and the explanation of using autologous serum was given followed by written informed consent. All enrolled patients had Schirmer test values with nasal stimulation of less than $10 \mathrm{~mm}$.

\section{BACTERIAL CULTURE OF USED AUTOLOGOUS} SERUM

Since preservatives were not added to serum solutions, contamination during patient use was of concern. Cultures of the remaining serum following patient use was performed for possible contamination by bacteria or fungi.

FLOW CYTOMETRIC ANALYSIS OF MUC-1 ON CULTURED CONJUNCTIVAL EPITHELIUM

A conjunctival epithelial cell line, CCL.20.2 (American Type Culture Collection [ATCC], Rockville, MD, USA) was cultured in medium 199 (Gibco, Grand Island, NY, USA) supplemented with $10 \%$ fetal calf serum (FCS) (Gibco), 100 units $/ \mathrm{ml}$ penicillin, and 100 units/ml streptomycin. In this study, the medium was changed to FCS-free medium 1 day before the experiments, and then cells were treated with two different concentrations of human serum $(15 \%, 30 \%)$ for 24 hours. Normal human serum was separated from a healthy volunteer. The handling of human tissue samples complied with the tenets of the

Table 3 Ocular surface evaluation before and after serum application

\begin{tabular}{lllll}
\hline & Face score & Rose bengal & Fluorescein & BUT (s) \\
\hline Before & $7.9(0.9)$ & $5.3(3.6)$ & $5.6(3.4)$ & $4.5(3.5)$ \\
2 weeks & $5.3(2.3)^{\star}$ & $1.8(1.9)^{\star \star}$ & $2.2(2.2)^{\star \star}$ & $6.8(2.5)$ \\
4 weeks & $5.1(2.4)^{\star}$ & $1.7(2.5)^{\star \star}$ & $2.5(2.6)^{\star}$ & $7.5(2.6)$ \\
\hline
\end{tabular}

${ }^{\star} \mathrm{p}<0.05$ compared with the value before the serum application.

${ }^{\star \star} \mathrm{p}<0.01$ compared with the value before the serum application.
Table 4 Expression of MUC-1 on CCL.20.2

\begin{tabular}{ll}
\hline Cell treatment & Fluorescence intensity \\
\hline Serum free & 4.2 \\
Human serum $15 \%$ & 11.4 \\
Human serum $30 \%$ & 13.1 \\
\hline
\end{tabular}

Declaration of Helsinki, and proper consent and approval were obtained before all experiments where appropriate.

Cells were reacted with anti-MUC-1 core protein antibody (Novocastra Laboratories Ltd, Newcastle, Tyne) for 1 hour at $4^{\circ} \mathrm{C}$. After washing, the cells were reacted with fluorescein labelled goat anti-mouse $(\lg G+\lg M)$ antibody (Tago, Burlingame, CA, USA), and then analysed by an EPICS-XL flow cytometer (Courter Electronics, Hialeah, FL, USA).

\section{Results}

PRESERVATION OF SERUM COMPONENTS

Serum preparation was obtained from 10 normal healthy volunteers (five females and five males, average age of 45.5 (SD 12.3) years) and the concentration of EGF, vitamin $\mathrm{A}$, and TGF- $\beta 1$ were measured at the beginning, 1 week, and 1 month after preservation in the refrigerator $\left(-4^{\circ} \mathrm{C}\right)$. The mean $(\mathrm{SD})$ value of the three variables were $0.52(0.08) \mathrm{ng} / \mathrm{ml}$ for EGF, $45.5(19.1) \mu \mathrm{g} / \mathrm{dl}$ for vitamin A and 33.2 (6.8) $\mathrm{ng} / \mathrm{ml}$ for TGF- $\beta 1$ at the initial period, and did not significantly change during the 1 month preservation period (Table 1).

The effect of longer preservation in the freezer $\left(-20^{\circ} \mathrm{C}\right)$ was examined in another group of 10 healthy volunteers (eight females, two males, average age of 55.5 (13.5) years). The above components were measured on the initial day, at 1 month, and 3 months after preservation in the freezer. The concentration of each component did not change during the 3 month preservation period (Table 2).

\section{EFFECT OF AUTOLOGOUS SERUM FOR THE} TREATMENT OF SS DRY EYE

The face score was $7.9(0.9)$ before treatment, which improved to $5.3(2.3)$ at 2 weeks and 5.2 (5.1) at 4 weeks with serum application $(\mathrm{p}<0.05)$.

Rose bengal and fluorescein scores before and after treatment are shown in Table 3. There was a significant improvement in both scores after serum application; however, no significant change in BUT scores was observed.

BACTERIAL CULTURE OF STORED SERUM

Patients were instructed that meticulous attention should be paid to the possible contamination of bottles since no preservatives were added to the serum. However, none of the collected samples were culture positive for either bacteria or fungi ( $n=12$ at 2 weeks of preservation).

MUC-1 EXPRESSION

CCL.20.2 expressed a significant amount of MUC-1 spontaneously, compared with the negative control performed with an isotype matched unrelated mAb. Application of 

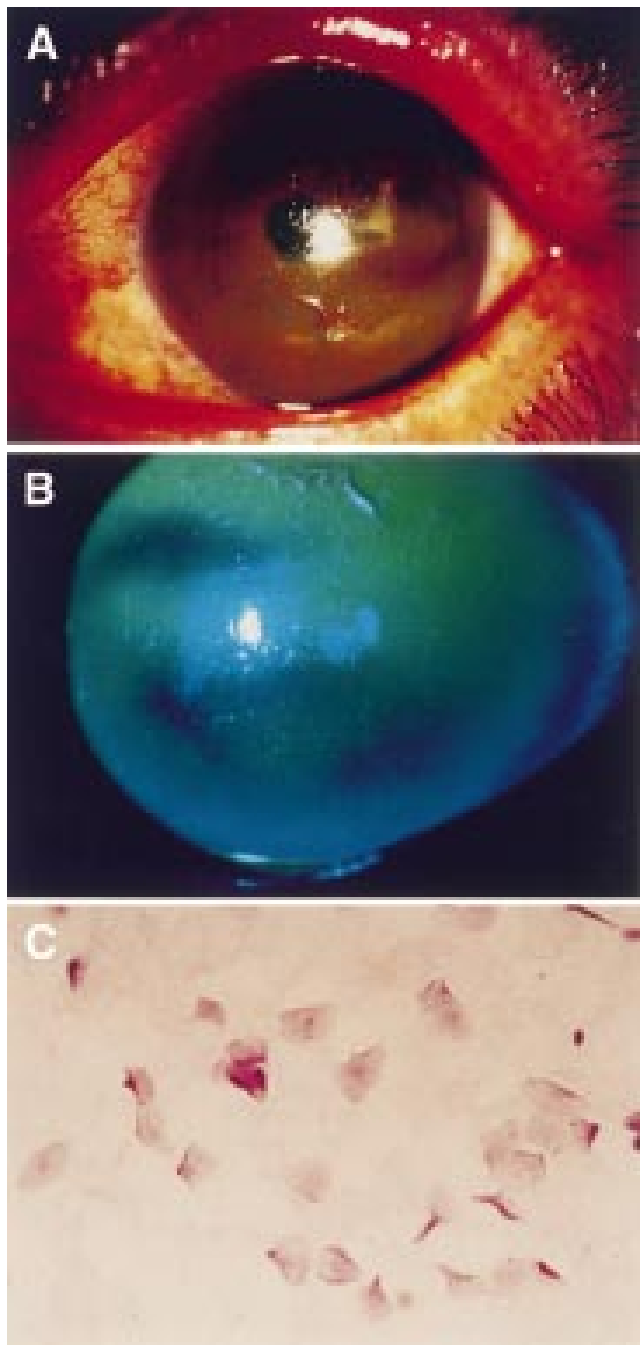

Figure 2 Slit lamp photographs stained by rose bengal and fluorescein of the left eye of the patients described $(A$, $B$ ). Note the corneal epithelium was deeply stained by fluorescein. Impression cytology of the bulbar conjunctiva in patients with Sjögren's syndrome (C) stained by PAS staining. There are no goblet cells observed. The epithelial cells are enlarged showing the squamous metaplasia.

human serum increased the expression of MUC-1 on CCL.20.2 in a dose dependent manner (Table 4).

CASE REPORT

A 71 year old woman had been suffering from Sjögren's syndrome over the past 10 years. The patient had no ocular abnormalities except for severe dry eye and senile cataract. The Schirmer test result was $5 \mathrm{~mm}$ in the right and $4 \mathrm{~mm}$ in the left eye, with tear clearance rate of $2 x$ in both eyes. The calculated tear function index of each eye was 10 in the right and 8 in the left. The Schirmer test with nasal stimulation was also less than $5 \mathrm{~mm}$ in both eyes.

Although the patient was treated with a combination of various treatments such as preservative-free eye drops, eye glasses with moisture inserts, and $0.3 \%$ hyaluronic acid, rose bengal and fluorescein staining was prominent (Fig 2A, B). Her corrected visual acuity was also impaired to $20 / 50$ in the right eye and 20/200 in the left eye. Impression cytology showed a lack of goblet cells and
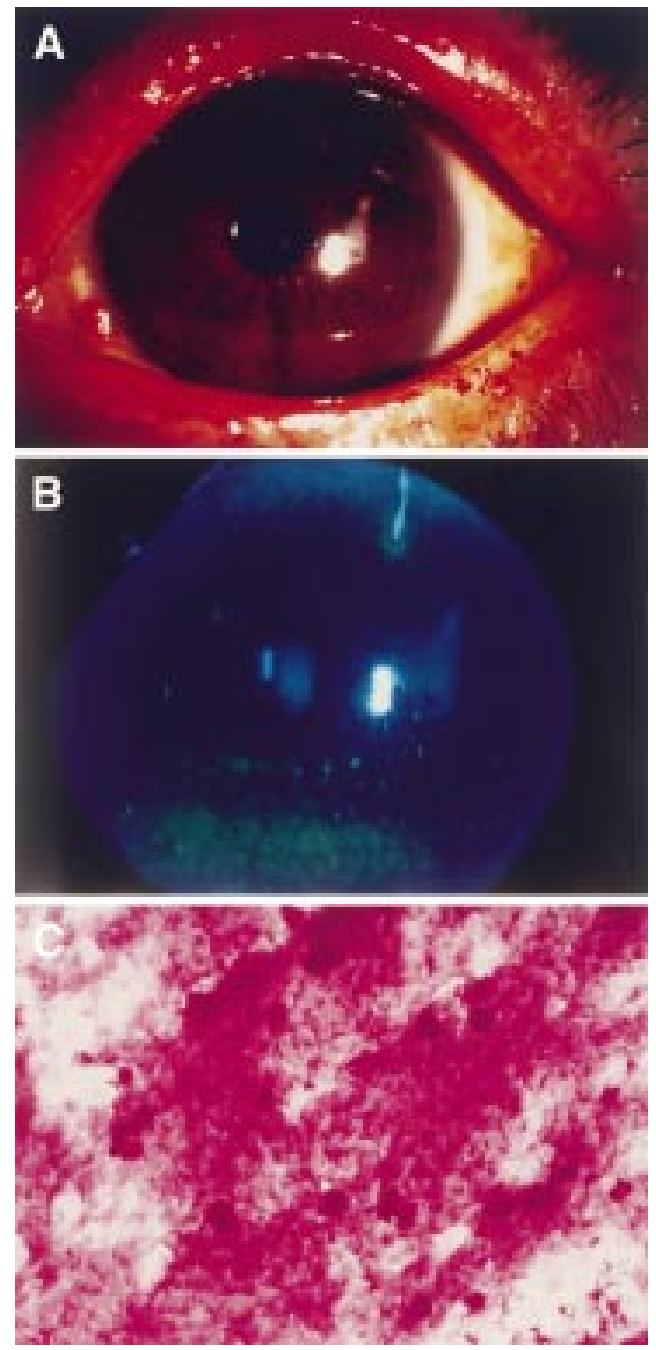

Figure 3 Slit lamp photographs stained by rose bengal and fluorescein of the left eye of the patients after the autologous serum treatment for 1 month. $(A, B)$ Note the corneal epithelium dramatically improved. Impression cytology of the bulbar conjunctiva in patients with Sjögren's syndrome also improved $(C)$. Goblet cells are observed with smaller epithelial cells.

severe squamous metaplasia in the bulbar conjunctiva by impression cytology (Fig 2C). The patient was placed on autologous serum application 10 times a day.

Subjective complaints were severe before treatment (face score of 9) which decreased to 6 after 4 weeks treatment. Rose bengal and fluorescein staining improved dramatically after serum application (Fig 3A, B). Impression cytology showed the appearance of goblet cells and improvement of squamous metaplasia (Fig 3C).

\section{Discussion}

This study demonstrated a clear benefit of using autologous serum for the treatment of dry eye associated with Sjögren's syndrome. We postulated that the theoretical background of using serum is the supplementation of important tear components that may be lacking in severe dry eyes. We measured EGF, vitamin $A$, and TGF- $\beta$ concentrations in serum and found that these components can be supplied to the ocular surface by this 
method. Furthermore, it was confirmed that the autologous serum samples can be preserved for more than 1 month in the refrigerator and more than 3 months in the freezer.

Dry eye is now categorised into two types; one is dry eye associated with tear deficiency, and the other is associated with increased tear evaporation. ${ }^{28}$ The first type of dry eye is further divided to Sjögren's dry eye and non-Sjögren's dry eye. In non-Sjögren's dry eye, only basic tearing is affected and the ocular surface alteration is minimal, although subjective complaints are often similar to SS dry eye. ${ }^{212}$ In SS dry eye, increased vital staining, squamous metaplasia observed by impression cytology and increased lymphocyte infiltration of the ocular surface observed by brush cytology are the major alterations compared with the non-SS dry eye. ${ }^{29}$

Fundamental treatment for SS dry eye is yet to be developed. There is no medication that stimulates secretion of the patient's own tears; therefore, the alleviation of symptoms is the major aim of currently available treatments. ${ }^{28}{ }^{30}$ Basically, dry eye is thought to be caused by desiccation, drying of the ocular surface, and it is important to use all possible measures to keep the ocular surface wet. This includes methods such as increased blinking, placing the video display terminal in a low position so that patients can look down and narrow their palpebral fissure, the use of dry eye glasses to increase the environmental humidity, and the frequent use of artificial tears. ${ }^{17-35}$ These treatments are effective to some extent, but the squamous metaplasia observed on the ocular surface of SS dry eye patients cannot be reversed by these conventional treatments.

Recent research has shown the importance of tear components for maintaining a healthy ocular surface epithelium. There are many essential factors present in tears such as EGF and vitamin A. ${ }^{67911}$ Ohashi et al reported that $\mathrm{EGF}$ is present in basic and reflex tears followed by several studies that demonstrated that EGF is effective for the acceleration of corneal epithelial proliferation. ${ }^{8}$ The concentration of EGF in tears is reported to be $0.7-8.1 \mathrm{ng} / \mathrm{ml}$ in reflex tears and $1.9-9.7 \mathrm{ng} / \mathrm{ml}$ in non-reflex tears, which is higher than EGF in serum which ranges around $0.5 \mathrm{ng} / \mathrm{ml}$. In contrast, the amounts of retinol in human tear has been reported by Speek et $a^{\beta 6}$ to be $0.4-10.6 \mathrm{ng} / \mathrm{ml}$. Since the concentration of retinol in serum is around $55 \mu \mathrm{g} / \mathrm{ml}$, serum contains more than 1000 times the amount available in tears. When vitamin A is lacking, the epithelium tends to undergo squamous metaplasia. $^{3738}$ Application of serum may provide higher levels of retinol necessary in pathological conditions.

Tear TGF- $\beta$ is somewhat more controversial. Wilson et al ${ }^{39}$ reported in 1991 that there were no mRNA of TGF- $\beta 1$ in the lacrimal gland, but Gupta et al ${ }^{18}$ reported that it is present around the level of $10 \mathrm{ng} / \mathrm{ml}$ in human tear. The TGF- $\beta$ concentration in human serum is around $50 \mathrm{ng} / \mathrm{ml}$ which is five times higher than in tears. TGF- $\beta$ is believed to control epithelial proliferation, and to maintain cells in an undifferentiated state such as the induction of the basic keratins in epidermal cells.

The concentration of biologically active molecules is different in serum and tear fluids. However, since many of the essential components in tears are also present in serum, the use of serum as a tear substitute for the maintenance of the ocular surface seems feasible. There is always the possibility that serum may contain components that are detrimental to the ocular surface. TGF- $\beta$, for example, is known to have antiproliferative effects, and high concentrations of TGF- $\beta$ may suppress wound healing of the ocular surface epithelium. This was one of the reasons for using a diluted solution of serum in order to maintain TGF- $\beta$ levels comparable with tears. Dilution also has the benefit of obtaining larger amounts of serum eye drops from one sample. Further study is necessary to determine the most effective concentration of serum.

It is interesting to note that the components in serum were stable in the refrigerator for 1 month and in the freezer for 3 months. In serum, there are many proteins such as albumin or globulin which can protect the degradation of important cytokines. Although the mechanism is unknown, the prolonged preservation of these components in serum makes autologous application clinically possible. With this knowledge, we obtained $40 \mathrm{ml}$ of blood from SS patients every 3 months. A $40 \mathrm{ml}$ sample of venous blood from SS patients is enough to last for at least 3 months. Twenty $\mathrm{ml}$ of serum can be obtained from $40 \mathrm{ml}$ of whole blood, while diluting 1:5 with saline provides $100 \mathrm{ml}$ serum solution. If each eye drop is 50 $\mu 1,2000$ drops can be obtained from $100 \mathrm{ml}$. SS dry eye patients use a maximum of 20 drops a day (10 times for each eye), thus 2000 drops are enough for more than 100 days. Patients are supplied with twenty $5 \mathrm{ml}$ bottles of $20 \%$ autologous serum and are advised to store bottles in the freezer until use. They were advised to keep bottles in current use in the refrigerator.

It should be noted that the contamination of autologous serum by bacteria or fungi was not observed in our study. Since serum contains many antibacterial agents such as IgG, lysozyme, and complement, serum alone may have some bacteriostatic effects. This may be the reason for the low rate of contamination of the serum bottles. This offers the advantage of no additional preservatives which may cause side effects. However, a more extensive study concerning the safety of this procedure is required before a large scale clinical study can be undertaken.

Objective observations of rose bengal and fluorescein scores dramatically improved in these patients. Since all patients have been using conventional treatment before the study, the improvement can be considered to be due to the effects of serum application. We speculate that EGF and vitamin A are the major components responsible, but other components in serum may also contribute in the amelioration of SS dry eye. Our successful 
experience with ocular surface reconstruction in ocular pemphigoid and Stevens-Johnson syndrome is also evidence that autologous serum as a tear substitute is adequate for maintaining the ocular surface epithelium. ${ }^{15}{ }^{16} \mathrm{In}$ addition to the improvement in objective scores, many patients reported the relief of discomfort and pain. The satisfaction rate of using autologous serum was high, and many patients wished to continue serum drops after their second visit.

The beneficial effect of autologous serum may be multifactorial. However, our simple experiment of the increased MUC-1 expression of cultured conjunctival epithelium suggested a direct effect of the serum on the ocular surface epithelium. Since rose bengal staining is believed to be due to the lack of mucin, the increased mucin expression can explain the dramatic effect on the improvement of vital staining in the clinical investigation.

The drawbacks of this treatment are of course the necessity to obtain blood from patients. Thus, the development of an ideal artificial tear substitute containing these essential components would be ideal. However, until such medication is available, the use of autologous serum according to the protocol provided in this study may be of great benefit for those in need.

This study was supported by grants from the Japanese Ministry of Health and Welfare and the Oral Health Center of Tokyo Dental College.

We would like to express our gratitude to Ms Michi Nakauchi and Mr Itsuo Yamamoto of the pharmaceutical department of Tokyo Dental College for their efforts in supplying the autologous serum drops.

1 Pflugfelder S, Huang A, Feuer W, et al. Conjunctival cytologic features of primary Sjögren's syndrome. Ophthalcytologic features of prim
mology 1990;97:985-93.

2 Tsubota K, Toda I, Yagi Y, et al. Three different types of dry eye syndrome. Cornea 1994;13:202-9.

Tsubota K. SS dry eye and non-SS dry eye: what are the differences? In: Homma M, Sugai S, Tojo T, Miyasaka N, Akizuki $M$, eds. Sjögren's syndrome. Amsterdam: Kugler, 1994:27-31

4 Xu K, Katagari S, Takeuchi T, et al. Biopsy of labial salivary glands and lacrimal glands in the diagnosis of Sjögren's syndrome. $\mathcal{F}$ Rheumatol 1996;23:76-82.

5 Tsubota $\mathrm{K}$. The importance of the Schirmer test with nasal stimulation [letter]. Am f Ophthalmol 1991;111:106-8.

6 Wilson S. Lacrimal gland epidermal growth factor production and the ocular surface. Am 7 Ophthalmol 1991;111: $763-5$

7 Ubels J, Loley K, Rismondo V. Retinol secretion by the lacrimal gland. Invest Ophthalmol Vis Sci 1986;27:1261-9.

8 Ohashi Y, Motokura M, Kinoshita Y, et al. Presence of epidermal growth factor in human tears. Invest Ophthalmol Vis Sci 1989;30:1879-87.

9 Van Setten G, Viinikka L, Tervo T. Epidermal growth factor is a constant component of normal human tear fluid. is a constant component of normal human te
Graefes Arch Clin Exp Ophthalmol 1989;22:184-7.

10 Van Setten G, Macauley S, Humphresy-Beher M, et al. Detection of transforming growth factor-alpha mRNA and protein in rat lacrimal glands and characterization of transforming growth-alpha in human tears. Invest Ophthalmol Vis Sci 1996;37:166-75.
11 Van Settten G, Tervo T, Tervo K, et al. Epidermal growth factor (EGF) in ocular fluids: presence, origin and
therapeutical considerations. Acta Ophthalmol 1992;202: therap 9 .

12 Tsubota K. Reflex tearing in dry eye not associated with Sjögren's syndrome. In: Sullivan D, ed. Lacrimal gland, tear film and dry eye syndromes 2. New York: Plenum Press, 903-7.

13 Fox R, Chan R, Michelson J, et al. Beneficial effect of artificial tears made with autologous serum in patients with keratoconjunctivitis sicca. Arthritis Rheum 1984;27:45961.

14 Tsubota K. New approaches in dry eye management: supplying missing tear components to the ocular surface epithelium. 1st Annual Meeting of Kyoto Cornea Club. epithelium. 1st Annual Meeting of

15 Tsubota K, Satake Y, Shimazaki J. Treatment of severe dry eye. Lancet 1996;348:123.

16 Tsubota K, Satake Y, Ohyama M, et al. Surgical reconstruction of the ocular surface in advanced ocular cicatricial pemphigoid and Stevens-Johnson syndrome. Am f Ophthalmol 1996;122:38-52.

17 Tsubota K, Yamada M, Urayama K. Spectacle side panels and moist inserts for the treatment of dry-eye patients. Cornea 1994;13:197-201.

18 Gupta A, Monroy D, Ji Z, et al. Transforming growth factor beta-1 and beta-2 in human tear fluid. Curr Eye Res 1996; 15:605-14.

19 Hirata Y, Orth D. Epidermal growth factor (Urogastrone) in human fluids: size heterogeneity. $\mathcal{F}$ Clin Endocrinol Metab 1979;48:673-9.

20 Katsui G. Assay methods of vitamin A in blood and tissues. Vitamins (Japanese) 1982;56:97-101.

21 Tsubota K, Xu K, Fujihara T, et al. Decreased reflex tearing is associated with lymphocyte infiltration in lacrimal and salivary glands. Rheumatology 1996;23:313-20.

22 Toda I, Tsubota K. Practical double vital staining for ocular surface evaluation. Cornea 1993;12:366-7.

23 Tseng S. Staging of conjunctival squamous metaplasia by impression cytology. Ophthalmology 1985;92:728-33.

24 Hamano $\mathrm{H}$, Hori $\mathrm{M}$, Hamano $\mathrm{T}$, et al. A new method for measuring tears. CLAO ₹ 1983;9:281-9.

25 Toda I, Shimazaki J, Tsubota K. Dry eye with only decreased tear break-up time is sometimes associated with allergic conjunctivitis. Ophthalmology 1995; 102:302-9.

26 Toda I, Yagi Y, Hata S, et al. Excimer laser photorefractive keratectomy for patients with contact lens intolerance keratectomy for patients with contact lens into
caused by dry eye. Br $\mathcal{7}$ Ophthalmol 1996;80:604-9.

27 Fox R, Saito I. Criteria for diagnosis of Sjögren's syndrome. Rheum Dis Clin North Am 1994;20:391-407.

28 Lemp MA. Report of the National Eye Institute/Industry workshop on Clinical Trials in Dry Eyes. CLAO F 1995;21: 221-32

29 Hikichi T, Yoshida A, Tsubota K. Lymphocytic infiltration of the conjunctiva and the salivary gland in Sjögren's syndrome. Arch Ophthalmol 1993;111:21-2.

30 Lemp MA. Recent developments in dry eye management. Ophthalmology 1987;94:1299-305.

31 Farris R. The dry eye: its mechanism and therapy, with evidence that contact lens is a cause. CLAO f 1986;12:23446

32 Tsubota K, Nakamori K. Dry eyes and video display terminals. N Engl f Med 1993;328:584.

33 Tsubota K. New approaches to dry-eye therapy. Int Phthalmol Clin 1994;34:115-28.

34 Tsubota K, Nakamori K. Effects of ocular surface area and blink rate on tear dynamics. Arch Ophthalmol 1995;113: 155-8.

35 Tsubota K, Toda I, Nakamori K. Poor illumination, VDTs and desiccated eyes. Lancet 1996;347:768-9.

36 Speek AJ, van Agtmaal EJ, Saowakontha S, et al. Fluorometric determination of retinol in human tear fluid using high-performance liquid chromatography. Curr Eye Res $1986 ; 5: 841-5$

37 Tseng S, Farazdaghi M, Rider A. Conjunctival transdifferentiation induced by systemic vitamin A deficiency in vascularized rabbit corneas. Invest Ophthalmol Vis Sci 1987;28: 1497-504.

38 El-Ghorab M, Capone A, Underwood B, et al. Response of ocular surface epithelium to corneal wounding in retinoldeficient rabbits. Invest Ophthalmol Vis Sci 1988;29:16716.

39 Wilson S, Lloyd S, Kennedy R. Basic fibroblast growth factor $(\mathrm{FGFb})$ and epidermal growth factor $(\mathrm{EGF})$ receptor messenger RNA production in human lacrimal gland. Invest Ophthalmol Vis Sci 1991;32:2816-20. 